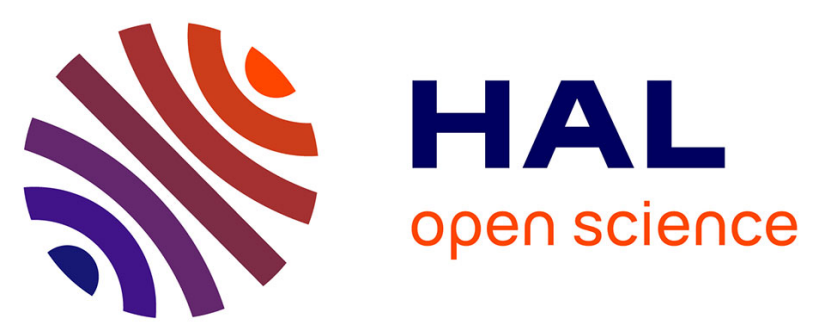

\title{
NEW FLUORINATED POLYMERS BEARING PENDANT PHOSPHONIC GROUPS FOR FUEL CELL MEMBRANES. PART 1 SYNTHESIS AND CHARACTERIZATIONS OF THE FLUORINATED POLYMERIC BACKBONE
}

Russell Tayouo, Ghislain David, B. Ameduri

\section{To cite this version:}

Russell Tayouo, Ghislain David, B. Ameduri. NEW FLUORINATED POLYMERS BEARING PENDANT PHOSPHONIC GROUPS FOR FUEL CELL MEMBRANES. PART 1 SYNTHESIS AND CHARACTERIZATIONS OF THE FLUORINATED POLYMERIC BACKBONE. European Polymer Journal, 2010, 46, pp.1111-1118. 10.1016/j.eurpolymj.2010.01.011 · hal-00447391

\author{
HAL Id: hal-00447391 \\ https://hal.science/hal-00447391
}

Submitted on 14 Jan 2010

HAL is a multi-disciplinary open access archive for the deposit and dissemination of scientific research documents, whether they are published or not. The documents may come from teaching and research institutions in France or abroad, or from public or private research centers.
L'archive ouverte pluridisciplinaire HAL, est destinée au dépôt et à la diffusion de documents scientifiques de niveau recherche, publiés ou non, émanant des établissements d'enseignement et de recherche français ou étrangers, des laboratoires publics ou privés. 


\title{
NEW FLUORINATED POLYMERS BEARING PENDANT PHOSPHONIC GROUPS \\ FOR FUEL CELL MEMBRANES. PART 1 SYNTHESIS AND CHARACTERIZATIONS OF THE FLUORINATED POLYMERIC BACKBONE
}

\author{
Russell Tayouo ${ }^{1}$, Ghislain David ${ }^{1}$, Bruno Améduri ${ }^{1}$ \\ ${ }^{1}$ Institut Charles Gerhardt UMR CNRS 5253 Laboratoire Ingénierie et Architecture \\ Macromoléculaire, Ecole Nationale Supérieure de Chimie de Montpellier, 8 rue de l'Ecole \\ Normale, 34296 Montpellier Cedex 05, France
}

\begin{abstract}
Radical copolymerizations of chlorotrifluoroethylene (CTFE) with vinyl ethers such as 2chloroethyl vinyl ether (CEVE) and ethyl vinyl ether (EVE) were performed at $75{ }^{\circ} \mathrm{C}$ in the presence of peroxide initiator. Three copolymers were obtained and characterized by means of both NMR and elemental analysis. Then, the chlorine atoms in the side chains were converted into iodine atoms by nucleophilic substitution, which was monitored by ${ }^{1} \mathrm{H}$ NMR spectroscopy. A series of five copolymers with different amounts of iodine atoms in the side chains were thus obtained. These copolymers exhibited molecular weight values of about 25,000 g. $\mathrm{mol}^{-1}$, and the thermal analysis of the copolymers showed a starting degradation from about $220{ }^{\circ} \mathrm{C}$. The $\mathrm{T}_{\mathrm{g}}$ values were in the range of 34 to $41{ }^{\circ} \mathrm{C}$ and showed a linear dependance versus the content of iodine atoms.
\end{abstract}




\section{INTRODUCTION}

Fluorinated polymers exhibit remarkable properties such as chemical, thermal and electrical stability, inertness to acids, solvents and oils, low dielectric constant, low refractive index, low or non flammability, high resistance to ageing and oxidation, and low surface tension.[1,2] These polymers show low friction coefficient and relative permittivity, and they are strongly hydrophobic. For application in a polymer electrolyte fuel cells, they must be functionalized [3], and the choice of the protogenic group plays an important role in the proton conductivity of fuel cell separator materials. Up to now, the materials used for proton exchange membranes in fuel cell applications depend on the presence of water as proton carrier.[4] Although practicable at lower temperatures, water management at temperatures higher than $100{ }^{\circ} \mathrm{C}$ has a significant impact on the viability of the membrane electrode assembly and on overall operation of the system. Commercially available perfluorosulfonic acid (PFSA) polymers such as Nafion ${ }^{\circledR}$, Flemion ${ }^{\circledR}$, Hyflon ${ }^{\circledR}$ Ion, (now Aquivion ${ }^{\circledR}$ ), BAM-3G®, Fumion ${ }^{\circledR}$, Gore Select ${ }^{\circledR}$, Dow ${ }^{\circledR}, 3 \mathrm{M} ®$ or Aciplex® are references and emerging advanced membranes for proton exchange membrane fuel cells (PEMFCs), being characterized by high proton conductivity and chemical stability.[5,6] Their conductivity is dependent on the ambient relative humidity and their glass transition temperature limits their use to temperatures lower than $130{ }^{\circ} \mathrm{C} .[4,7]$ Polymers functionalized with alternative protogenic groups, including phosphonic acids[8,9] and different heterocycles[10], have been investigated with the aim to overcome the shortcomings of the Nafion ${ }^{\circledR}$ membrane.[5] Phosphonic acid derivatives in particular are considered suitable candidates as ionomers because of their efficient proton transport according to the Grotthuss mechanism.[10-16] They are both amphoteric and possess a relatively high dielectric constant. Moreover, they are able to perform even in anhydrous conditions. The combination of these properties is an important requirement for membranes operating in medium to high temperature regimes. Several phosphonic acid containing polymers have been developed for fuel cell applications, starting from polyvinylphosphonic acid (PVPA)[17] to less flexible polymers such as polysulfones.[8,18] To our knowledge, only Kotov 
et al.[19] and Yamabe et al.[20] connected phosphonic acid functions to a flexible fluorinated polymeric backbone. Indeed, these authors synthesized new fluorinated monomers, bearing a phosphonic group, able to copolymerize with fluorinated olefins such as TFE. However, poor conductivity values were reached due to the low content of incorporated phosphonic group into the fluorinated backbone.

We suggest here another approach, which consists in the chemical modification of fluorinated polymers into ionomers bearing a high content of phosphonic acid groups. The objective of this article is to provide a series of fluorinated copolymers as precursors containing a controlled amount of $\omega$-iodoalkyl pendant groups tethered to the backbone. In a second part, these iodine atoms will be modified into phosphonic groups (via the Arbuzov reaction) and the properties of the resulting membranes will be analyzed. This second part will be devoted to a forthcoming paper. The synthesis of fluorinated copolymers bearing iodine atoms can be achieved by radical copolymerization of fluorinated olefins, such as chlorotrifluoroethylene (CTFE), with vinyl ethers (VEs), such as 2-chloroethyl vinyl ether (CEVE) or ethyl vinyl ether (EVE). These radical copolymerizations usually result in alternated copolymers[21-25], which enable to incorporate a high amount of chlorine atoms (from CEVE). These chlorine atoms can be further modified into iodine atoms by nucleophilic substitution.[26] A series of five fluorinated copolymers based on CTFE, CEVE and EVE with a controlled amount of iodine atom is provided. These copolymers have been deeply characterized and a special attention will be paid to the determination of the halogen atom content that will govern the range of ionic exchange capacity (IEC) values.

\section{EXPERIMENTAL SECTION}

\section{Materials.}

Chlorotrifluoroethylene (CTFE) and 1,1,1,3,3-pentafluorobutane were kindly provided by Solvay S.A. Vinyl ethers such as 2-chloroethyl vinyl ether (CEVE) and ethyl vinyl ether (EVE) were purchased from Acros Organics. Diethyl ether and methanol were purchased from Aldrich, $\mathrm{K}_{2} \mathrm{CO}_{3}$ 
from SDS and tert-butyl peroxipivalate (TBPPI) 75\% purity from Azko Nobel. All reactants were used without further purification except for 1,1,1,3,3-pentafluorobutane, which was distillated prior to use.

\section{Characterization.}

${ }^{1} \mathrm{H},{ }^{13} \mathrm{C}$ and ${ }^{19} \mathrm{~F}$ nuclear magnetic resonance (NMR) spectra were recorded at room temperature on Bruker AC 400 instrument, using deuterated chloroform as the solvent. In the figures and discussion below, the letters $\mathrm{s}, \mathrm{d}, \mathrm{t}, \mathrm{q}$ and $\mathrm{m}$ stand for singlet, doublet, triplet, quintet and multiplet, respectively. Coupling constants and chemical shifts are given in Hertz (Hz) and ppm. The experimental conditions to record ${ }^{1} \mathrm{H},{ }^{13} \mathrm{C}$ and ${ }^{19} \mathrm{~F}$ NMR spectra were as follows: flip angle $90^{\circ}, 30^{\circ}$ and $30^{\circ}$; acquisition time: $4.5 \mathrm{sec}, 2.9 \mathrm{sec}$ and $0.7 \mathrm{sec}$; pulse delay : $2 \mathrm{sec}, 2 \mathrm{sec}$ and 5 sec ; number of scans: 16,12000 and 64 , and a pulse width of $5 \mu \mathrm{sec}$ for ${ }^{19} \mathrm{~F}$ NMR.

Thermogravimetric analyses (TGA) were performed with a TGA/SDTA 851 thermobalance from Mettler DAL 75965 and Lauda RC6 CS cryostat apparatus in static air with a heating rate of 10 ${ }^{\circ} \mathrm{C} . \mathrm{min}^{-1}$ from room temperature up to a maximum of $600{ }^{\circ} \mathrm{C}$. Differential scanning calorimetry (DSC) measurements were conducted using a TA2920 analyzer from TA Instruments DA 73085, an RCS DA cooler and Sartorius MC5 balance. Scans were recorded at a heating/cooling rate of $20{ }^{\circ} \mathrm{C} \cdot \mathrm{min}^{-1}$ from $-100{ }^{\circ} \mathrm{C}$ to $100{ }^{\circ} \mathrm{C}$ and the $\mathrm{T}_{\mathrm{g}}$ value was assessed from the inflexion point in the heat capacity jump.

Size exclusion chromatography (SEC) measurements were conducted on a Spectra-Physics apparatus equipped with two $5 \mu \mathrm{m}$ Mixed-C PL-gels columns (Polymer Laboratories), a SP8430 Spectra-Physics refractive index detector using THF as the eluent at room temperature, and a flow rate of $0.6 \mathrm{~mL} \cdot \mathrm{mn}^{-1} \mathrm{~min}$. Monodispersed polystyrene standards were used for the calibration.

Weight percentages of carbon, fluorine, chlorine, and hydrogen atoms were assessed by elemental analysis at the CNRS-Service Central d'Analyze (Solaize, France) on a $\mathrm{CH}$ elemental analyzer equipped with a $\mathrm{CO}_{2} / \mathrm{H}_{2} \mathrm{O}$ infrared detector. Theoretical carbon and hydrogen compositions were calculated according to the polymer compositions assessed by ${ }^{1} \mathrm{H}$ and ${ }^{19} \mathrm{~F}$ NMR spectroscopy and 
considering that co- or terpolymers have alternating structures (i.e., $50 \%$ of fluorinated olefins and $50 \%$ of vinyl ethers).

\section{Radical copolymerizations}

As CTFE is a gaz, the reactions were carried out in a Hastelloy (HC276) autoclave Parr system equipped with a manometer, a rupture disk (3000 psi), inlet and outlet valves, and a magnetic stirrer. Prior to reaction, the autoclave was pressurized with 30 bar (i.e., 430 psi) of nitrogen to check for eventual leaks. The autoclave was then conditioned for the reaction with several nitrogen/vacuum cycles $\left(10^{-2} \mathrm{mbar}\right)$ to remove any traces of oxygen. The liquid phase was first introduced via a funnel, and then the gases were inserted by double weighing (i.e., the difference of weight before and after filling the autoclave with the gas). Then, the autoclave was placed in a mantle heated with a vigorous mechanical stirring. Both heating and stirring were monitored by a controller. After an initial increase of the internal pressure due to the increasing temperature, the pressure dropped by consumption of the gaseous monomer to produce a polymer in the liquid phase. After the reaction was complete, the autoclave was cooled to room temperature and then degassed. After distillation of the solvent, the copolymers were precipitated from cold pentane. The product was dried under vacuum $\left(10^{-2} \mathrm{mbar}\right)$ at $70{ }^{\circ} \mathrm{C}$ until constant weight.

\section{Synthesis of $(\mathrm{F}: \mathrm{Cl})$}

As an example, 1,1,1,3,3-pentafluorobutane $(150 \mathrm{ml})$ as the solvent, tert-butylperoxypivalate 1.04 $\mathrm{g}(5.75 \mathrm{mmol})$ as the initiator, potassium carbonate $0.79 \mathrm{~g}(5.72 \mathrm{mmol})$ (to prevent the cationic homopolymerization of CEVE), CEVE $20.2 \mathrm{~g}$ (187.71 mmol) and CTFE $25 \mathrm{~g}$ (214.74 mmol) were introduced in the autoclave. The reaction was allowed to proceed at $75{ }^{\circ} \mathrm{C}$ for $12 \mathrm{~h}$, showing a drop of pressure as CTFE was reacting. After purification, the copolymer, obtained as a white powder, was then dried in a vacuum oven $\left(10^{-2} \mathrm{mbar}\right)$ at $50^{\circ} \mathrm{C}$ until constant weight. The mass yield was $75 \%$. 


\section{Nucleophilic substitution}

The copolymer was dissolved in dry acetone in a single-neck round bottom flask equipped with a magnetic stirrer and a condenser. Then, 3 equiv of sodium iodide were introduced in the flask, and the reaction was allowed to reflux for 7 days. After reaction and upon cooling to room temperature, the produced salts (sodium chloride and sodium iodide) were filtered off. Then, the polymer was precipitated from methanol and dried under vacuum at $50{ }^{\circ} \mathrm{C}$ for $4 \mathrm{~h}$ to produce a white powder. The product was obtained in high yield ( $>81 \%)$.

\section{RESULTS AND DISCUSSION}

Valade et al.[26] performed the radical copolymerizations of vinyl ethers with chlorotrifluoroethylene (CTFE) and hexafluoropropylene (HFP). HFP allowed the incorporation of a higher content of fluorine moities into the copolymers. However, the resulting terpolymers showed low molecular weights, i.e. $<8000 \mathrm{~g} / \mathrm{mol}$, and thus polymeric membranes cannot be obtained. Hence, the radical copolymerizations of 2-chloroethyl vinyl ether (CEVE) with only CTFE were developed, the content of halogen, i.e. chlorine and then iodine, will be tuned by a controlled incorporation of ethyl vinyl ether (EVE).

\section{Radical copolymerizations of CTFE with $V E$}

NMR computational results of poly(CTFE-alt-VE) copolymers, and especially poly(CTFE-altEVE), allowed to assess the alternated structure of these copolymers.[27] Hence, alternated copolymers were synthesized by radical copolymerizations of CTFE with CEVE and EVE at 75 ${ }^{\circ} \mathrm{C}$ initiated with tert-butyl peroxypivalate (TBPPI) (Figure 1). Three copolymers were obtained. The first one did not contain any EVE units and was labelled (F:Cl), the two others contained both CEVE and EVE units were labelled $(\mathbf{F}: \mathbf{C l})_{\mathbf{x}}-\mathbf{c o}-(\mathbf{F}: \mathbf{E})_{\mathbf{y}}$; where $\mathrm{x}$ and y represent the molar contents of oligo(CTFE-alt-CEVE) and oligo(CTFE-alt-EVE) units into the copolymers, 
respectively. Indeed, these copolymers can be represented as a molar content of acceptor/donnor (A/D) couples, i.e. CTFE/CEVE and CTFE/EVE, since the mechanism of radical copolymerization proceeds via the formation of a charge transfer complex followed by its radical polymerization.[25] A series of three copolymers was obtained with $\mathrm{x}$ value ranging from 0.36 to 1 (Table 1) and the yields of the corresponding copolymers were up to $75 \%$ (wt. \%). These copolymers were first characterized by elemental analysis. Experimental weight percentages of carbon, hydrogen, fluorine, chlorine and oxygen are in good agreement with the calculated theoretical values assuming an alternating copolymer structure (Table 2). NMR study was then conducted to determine the structure of the copolymers. The ${ }^{1} \mathrm{H}$ NMR spectrum (Figure 2) allows reaching the composition of each A/D couples, i.e. $(\mathbf{F}: \mathbf{C l})$ and $(\mathbf{F}: \mathbf{E})$ by using intensities of signals corresponding to both $\mathrm{CH}_{3}$ (e) and $\mathrm{CH}(\mathrm{OR})$ (b) centered at 1 and $4.5 \mathrm{ppm}$, respectively. The ${ }^{1} \mathrm{H}$ NMR analysis also affords a chain end characterization. Indeed, ${ }^{1} \mathrm{H}$ NMR spectra seem to underline some chain transfer reactions (from hydrogen radical) leading to dead polymer chains. These transfer reaction seem to occur towards the fluorinated macroradical terminated by $\mathrm{CF}_{2} \mathrm{CFCl}^{\circ}$ and the resulting terminal chain shows a complex signal centered at about $6.5 \mathrm{ppm}$ assigned to the proton in $-\mathrm{CF}_{2} \mathrm{CFClH}$. Boutevin et al.[25] already observed this termination by performing the radical transfer reaction of CTFE in the presence of a chain transfer agent. Deeper investigations are required to understand these transfer reactions, nevertheless they remain negligeable. It is also noted a series of signals centered between 1.14 and $1.58 \mathrm{ppm}$ that can be attributed to methyl and t-butyl groups arising from TBPPi decomposition.

${ }^{13} \mathrm{C}$ NMR spectra (Figure 3a) also confirm the copolymer structure. As previously demonstrated by Carnevale et al.[27], two asymetrical carbon atoms (C2 and $\mathrm{C} 4)$ are observed in the backbone inducing 4 diastereoisomers for $(\mathbf{F}: \mathbf{C l})$ and 16 diastereoisomers for $(\mathbf{F}: \mathbf{C l})_{\mathbf{x}}-\mathbf{c o}-(\mathbf{F}: \mathbf{E})_{\mathbf{y}}$. Furthermore, coupling constants of 251 and $32 \mathrm{~Hz}$ were obtained for ${ }^{1} \mathrm{~J}_{\mathrm{CF}}$ and ${ }^{2} \mathrm{~J}_{\mathrm{CF}}$ of $\mathrm{CF}_{2}$ and $\mathrm{CFCl}$ carbons, respectively. Finally, ${ }^{19} \mathrm{~F}$ NMR spectrum (Figure $3 \mathrm{~b}$ ) shows a series of complex multiplets, centered at $-109.54,-115.75,-119.34$ and $-121.13 \mathrm{ppm}$, assigned to the presences of 
asymetric carbons into the backbone. No signal characteristic of bimolecular termination (e.g. CFCl-CFCl)[28] was observed on the ${ }^{19} \mathrm{~F}$ NMR spectrum. Molecular weight values of the copolymers were ca. 25,000 g.mol ${ }^{-1}$ (Table 3). They were low but sufficient to perform membranes from the corresponding copolymers. These low $M_{n}$ values are attributed to an exothermic effect observed in the course of the radical copolymerization. This exothermic effect increases the concentration of radicals which lead to initiation of new chains but also to termination reaction as well as transfer reaction (as mentioned above). This behavior results in highly polydispersed copolymers with polydispersity index (PDI) values of about 3 (Table 3).

Thermal properties of the three copolymers were determined by means of TGA and DSC (Table 3). Thermograms recorded under air of the copolymers show one main degradation step starting after $300{ }^{\circ} \mathrm{C}$ to reach a complete degradation after about $500{ }^{\circ} \mathrm{C}$. The EVE content of the copolymers influences the thermostability: the higher the EVE content, the higher the thermostability.[29-31] This can be connected to a lower amount of $\mathrm{CH}_{2}-\mathrm{CH}_{2}-\mathrm{Cl}$ units, because the dissociation energy of $\mathrm{C}-\mathrm{Cl}$ bond (from CEVE units) is about $285 \mathrm{KJ} \cdot \mathrm{mol}^{-1}$ whereas the energy of C-H bond (from EVE units) is higher (about $370 \mathrm{KJ}^{\mathrm{m}} \mathrm{mol}{ }^{-1}$ ).[32] Hence, the decrease of the thermostability is certainly due to the release of $\mathrm{HCl}$ which might further degradate the copolymer. This degradation is however observed at high temperature (about $300{ }^{\circ} \mathrm{C}$ ) and does not represent a main drawback because the operating temperatures in fuel cells are much lower (about $130{ }^{\circ} \mathrm{C}$ ). Table 3 also shows that the starting degradation temperatures under nitrogen are higher than those under air of about $40{ }^{\circ} \mathrm{C}$. In the last case, oxidation reactions occur and accelerate the thermal degradation of the copolymers. Despite, these temperatures of starting degradation remain acceptable for fuel cell application. Interestingly, glass transition temperatures of about $26{ }^{\circ} \mathrm{C}$ were obtained (Table 3), which will confer some flexibility to the resulting membranes. 


\section{Nucleophilic substitution of the copolymers}

The $\mathrm{CH}_{2}-\mathrm{Cl}$ groups in $(\mathbf{F}: \mathbf{C l})$ and $(\mathbf{F}: \mathbf{C l})_{\mathbf{x}}-\mathbf{c o}-(\mathbf{F}: \mathbf{E})_{\mathbf{y}}$ copolymers were partially or totally converted into $\mathrm{CH}_{2}-\mathrm{I}$ units by using the Finkelstein reaction, i.e. the nucleophilic substitution in the presence of $\mathrm{NaI}$ at $65{ }^{\circ} \mathrm{C}$ (Figure 5).[33] This chemical modification will enable these fluoroiodinated copolymers a more easily chemically grafting of the phosphonic groups, as the dissociation energy of the C-I bond is about $205 \mathrm{KJ} \mathrm{mol}^{-1}$ instead of $285 \mathrm{KJ} \cdot \mathrm{mol}^{-1}$ for C-Cl bond. This nucleophilic substitution was studied in a kinetic point of view by Valade et al.[26] to control the amount of $\mathrm{CH}_{2}$-I units, and hence to better control the final IEC of the resulting membranes. From the three fluorochlorinated copolymers, a series of five copolymers containing iodine side atoms was obtained with different $\mathrm{CH}_{2}-\mathrm{I}$ amounts, ranging from $30 \mathrm{~mol} . \%$ to 97 mol.\% (Table 4). These amounts were determined from ${ }^{1} \mathrm{H}$ NMR spectra (Figure 6) of the copolymers, especially by using the integrals of signals centered at 3.20 and $3.55 \mathrm{ppm}$ assigned to $\mathrm{CH}_{2}-\mathrm{I}$ and $\mathrm{CH}_{2}-\mathrm{Cl}$, respectively. The theoretical and experimental amounts of $\mathrm{CH}_{2}$-I groups (Table 4) are similar except for $(\mathbf{F}: \mathbf{C l})_{\mathbf{0 . 3 6}}-\mathbf{c o}-(\mathbf{F}: \mathbf{E})_{\mathbf{0 . 6 4}}$ where the high content of EVE units may increase the steric hindrance and thus may decrease the accessibility of the $\mathrm{CH}_{2}-\mathrm{Cl}$ groups. As expected, molecular weights of the five iodinated copolymers are in the same order as the neat copolymers (about 25,000 g. $\left.\mathrm{mol}^{-1}\right)$. Figure 7 shows the thermogravimetric analyses of $(\mathbf{F}: \mathbf{C l})_{\mathbf{0 . 0 3}}-\mathbf{c o}-(\mathbf{F}: \mathbf{I})_{\mathbf{0 . 9 7}}$, $(\mathbf{F}: \mathbf{C l})_{0.41}-\mathbf{c o}-(\mathbf{F}: \mathbf{I})_{0.59}$ and $(\mathbf{F}: \mathbf{C l})_{0.05}-\mathbf{c o}-(\mathbf{F}: \mathbf{E})_{0.64}-\mathbf{c o}-(\mathbf{F}: \mathbf{I})_{0.31}$ copolymers recorded under air. Three main degradations can be observed. The first one occurs from about $190{ }^{\circ} \mathrm{C}$ and corresponds to the release of $\mathrm{HI}$. The second one, starting from $230{ }^{\circ} \mathrm{C}$ until $430{ }^{\circ} \mathrm{C}$, is the main degradation for all the copolymers as more than $75 \%$ of weight loss is obtained, corresponding to the degradation of the polymeric backbone. The third one begins after $430{ }^{\circ} \mathrm{C}$ and is assigned to the decomposition of alkyl groups from the different vinyl ethers. It is also observed that the higher the iodine molar content, the lower the thermal stability of the copolymers. As expected, the thermostability noted under nitrogen is higher when less oxidation reactions occurred (Table 4). 
Furthermore, a slight decrease of the thermostability is obtained when the chlorine atoms were replaced by the iodine atoms due to the lower energy of C-I bond compared to that of $\mathrm{C}-\mathrm{Cl}$. This is clearly enhanced by the lowest thermostability of $(\mathbf{F}: \mathbf{C l})_{\mathbf{0 . 0 3}}-\mathbf{c o}-(\mathbf{F}: \mathbf{I})_{\mathbf{0 . 9 7}}$, which possesses the highest content of iodine atoms. The glass transition temperatures were assessed for the five copolymers (Table 4) and ranged from 34 to $41{ }^{\circ} \mathrm{C}$. As the molecular weight values of the five copolymers were similar (about $25,000 \mathrm{~g} \cdot \mathrm{mol}^{-1}$ ), the evolution of the $\mathrm{T}_{\mathrm{g}}$ values can be related to the iodine content. $\mathrm{T}_{\mathrm{g}}$ values were plotted versus the molar contents of the iodine atoms, more precisely to the 2-iodoethyl vinyl ether molar content. Interestingly, a linear trend was obtained (Figure 8) from which the graphical equation may afford a theoretical determination of the $\mathrm{T}_{\mathrm{g}}$ values, knowing both the molar contents of iodine atoms and the molecular weights of the copolymers.

\section{CONCLUSION}

Five fluorinated copolymers were synthesized by conventional radical polymerization of chlorotrifluoroethylene with vinyl ethers such as 2-chloroethyl vinyl ether and ethyl vinyl ether. The alternated behavior of this copolymerization led to a high amount of chlorine atoms in the side chains. That content was also monitored by incorporating a controlled amount of ethyl vinyl ether. Then, the chlorine atoms were quantitatively modified chemically into iodine atoms by nucleophilic substitution. These copolymers exhibit molecular weights values of ca. 25,000 g.mol ${ }^{-}$ ${ }^{1}$, which is satisfactory to process membranes. The main thermal degradation of the copolymers starts after $220{ }^{\circ} \mathrm{C}$ and is relatively dependent on the content of iodine atoms in the side chains. The $\mathrm{T}_{\mathrm{g}}$ values ranged from 34 to $41{ }^{\circ} \mathrm{C}$ and were directly related to the content of the iodine atoms. A forthcoming paper will report the conversion of these iodine atoms into phosphonic groups, leading to original copolymers bearing fluorinated and phosphonic acid moieties, and the behaviors of the resulting membranes will be examined in term of their protonic conductivity. 


\section{Acknowledgments}

The authors thank the Honeywell Company for providing with CTFE and Akzo Nobel for the generous gift of tert-butyl peroxypivalate. $\mathrm{Ph} \mathrm{D}$ grant attributed to $\mathrm{RT}$ from the "Ministère de la Recherche et de la Technologie » was also appreciated. 


\section{REFERENCES}

[1] B Ameduri; B Boutevin. Elsevier. Well-Architectured Fluoropolymers: Synthesis, Properties and Applications: Amsterdam, 2004.

[2] D W Brown; L A Wall. J. Polym. Sci, Polym. Chem. 1972; 10: 2967-82.

[3] J Roziere; D J Jones. Annual Review of Materials Research 2003; 33: 503-555.

[4] K-D Kreuer; T Dippel; J Maier. Proc. Electrochem. Soc. 1995; 95-23: 241-6.

[5] M A Hickner; H Ghassemi; Y S Kim; B R Einsla; J E McGrath. Chem. Rev. 2004; 104: $4587-4611$.

[6] M Rikukawa; K Sanui. Prog. Polym. Sci. FIELD Full Journal Title:Progress in Polymer Science 2000; 25: 1463-1502.

[7] R Souzy; B Ameduri. Prog. Polym. Sci. 2005; 30: 644-687.

[8] B Lafitte; P Jannasch. J. Polym. Sci., Part A Polym. Chem. 2006; 45: 269-283.

[9] L Gubler; D Kramer; J Belack; O Unsal; T J Schmidt; G G Scherer. J. Electrochem. Soc. 2007; 154: B981-B987.

[10] J C Persson; P Jannasch. Macromolecules 2005; 38: 3283-3289.

[11] M Schuster; T Rager; A Noda; K D Kreuer; J Maier. Fuel Cells 2005; 5: 355-365.

[12] M Schuster; K-D Kreuer; H Steininger; J Maier. Solid State Ionics 2008; 179: 523-528.

[13] T Rager; M Schuster; H Steininger; K-D Kreuer. Adv. Mater. 2007; 19: 3317-3321.

[14] H Steininger; M Schuster; K D Kreuer; A Kaltbeitzel; B Bingoel; W H Meyer; S Schauff; G Brunklaus; J Maier; H W Spiess. Phys. Chem. Chem. Phys. 2007; 9: 1764-1773.

[15] H Steininger; M Schuster; K D Kreuer; J Maier. Solid State Ionics 2006; 177: 2457-2462.

[16] S J Paddison; K-D Kreuer; J Maier. Phys. Chem. Chem. Phys. 2006; 8: 4530-4542.

[17] B Bingöl; W Meyer; M Wagner; G Wegner. Macromol. Rapid Commun. 2006; 27: 17191724.

[18] B Lafitte; P Jannasch. Adv. Fuel Cells 2007; 1: 119-185. 
[19] S V Kotov; S D Pedersen; W Qiu; Z-M Qiu; D J Burton. Journal of Fluorine Chemistry 1997; 82: 13-19.

[20] M Yamabe; K Akiyama; Y Akatsuka; M Kato. Eur. Polym. J. 2000; 36: 1035-1041.

[21] R Souzy; B Ameduri; B Boutevin. J. Polym. Sci., Part A: Polym. Chem. 2004; 42: $5077-$ 5097.

[22] M Gaboyard; Y Hervaud; B Boutevin. Polym. Int. 2002; 51: 577-584.

[23] B Ameduri; B Boutevin. J. Fluorine Chem. 2000; 104: 53-62.

[24] O Beaune; J M Bessiere; B Boutevin; A El Bachiri. J. Fluorine Chem. 1995; 73: 27-32.

[25] B Boutevin; F Cersosimo; B Youssef. Macromolecules 1992; 25: 2842-6.

[26] D Valade; F Boschet; B Ameduri. Macromolecules 2009; 42: 7689-7700.

[27] D Carnevale; P Wormald; B Ameduri; R Tayouo; S E Ashbrook. Macromolecules 2009; 42: $5652-5659$.

[28] Y Lu; J Claude; Q Zhang; Q Wang. Macromolecules 2006; 39: 6962-6968.

[29] S Zulfiqar; M Rizvi; A Munir; A Ghaffar; I C McNeill. Polym. Degrad. Stab. 1996; 52: 341-348.

[30] S Zulfiqar; M Zulfiqar; M Rizvi; A Munir; I C McNeill. Polym. Degrad. Stab. 1994; 43: 423-30.

[31] V Castelvetro; G B Pittaluga; F Ciardelli. Macromol. Chem. Phys. 2001; 202: 2093-2103.

[32] M L Huggins. J. Am. Chem. Soc. 1953; 75: 4123-6.

[33] M Hauser. J. Org. Chem. 1962; 27: 43-6. 


\section{Table Captions}

Table 1. Experimental conditions and compositions of poly(CTFE-alt-CEVE) and poly[(CTFEalt-CEVE)-co-(CTFE-alt-EVE)] copolymers where CTFE, CEVE and EVE stand for chlorotrifluoroethylene, 2-chloroethyl vinyl ether and ethyl vinyl ether, respectively.

Table 2. Elemental analyses of poly(CTFE-alt-CEVE) and poly[(CTFE-alt-CEVE)-co-(CTFE-altEVE)] copolymers assuming alternating structures (where CTFE, CEVE and EVE stand for chlorotrifluoroethylene, 2-chloroethyl vinyl ether and ethyl vinyl ether, respectively)

Table 3: Molecular weights, polydispersity indices and thermal properties of poly(CTFE-altCEVE) and poly[(CTFE-alt-CEVE)-co-(CTFE-alt-EVE)] copolymers. $\mathrm{T}_{\mathrm{d}, \mathrm{i} \%}$ stands for a thermal decomposition of $\mathrm{i} \%$ of the copolymer at the corresponding temperature (where CTFE, CEVE and EVE stand for chlorotrifluoroethylene, 2-chloroethyl vinyl ether and ethyl vinyl ether, respectively)

Table 4: Iodine subsitution, molecular weights and thermal properties of poly(CTFE-alt-CEVE) and poly[(CTFE-alt-CEVE)-co-(CTFE-alt-EVE)] copolymers after nucleophilic subtitution with NaI (where CTFE, CEVE and EVE stand for chlorotrifluoroethylene, 2-chloroethyl vinyl ether and ethyl vinyl ether, respectively) 


\section{Figure Captions}

Figure 1. Radical copolymerizations between chlorotrifluoroethylene and vinyl ethers (2chloroethyl vinyl ether and ethyl vinyl ether) in 1,1,1,3,3-pentafluorobutane initiated with tertbutylperoxypivalate (TBPPI) $(1 \% \mathrm{~mol})$ at $75^{\circ} \mathrm{C}$.

Figure 2. ${ }^{1} \mathrm{H}$ NMR spectrum $(\mathbf{F}: \mathbf{C l})_{0.56}$-co-(F:E $)_{0.44}$ copolymer (recorded in $\mathrm{CDCl}_{3}$ ).

Figure 3. ${ }^{13} \mathrm{C}$ NMR spectrum of $(\mathbf{F}: \mathbf{C l})_{\mathbf{0 . 5 6}}-\mathbf{c o -}(\mathbf{F}: \mathbf{E})_{\mathbf{0 . 4 4}}$ copolymer (recorded in $\left.\mathrm{CDCl}_{3}\right)$.

Figure 4. ${ }^{19} \mathrm{~F}$ NMR spectrum of $(\mathbf{F}: \mathbf{C l})$ copolymer (recorded in $\left.\mathrm{CDCl}_{3}\right)$.

Figure 5. Nucleophilic substitution of poly(CTFE-alt-CEVE) and poly[(CTFE-alt-CEVE)-co(CTFE-alt-EVE)] copolymers with $\mathrm{NaI}$ at $65^{\circ} \mathrm{C}$ in acetone

Figure 6. ${ }^{1} \mathrm{H}$ NMR spectrum of $(\mathbf{F}: \mathbf{C l})_{0.04}-\mathbf{c o}-(\mathbf{F}: \mathbf{E})_{\mathbf{0 . 4 4}}-\mathbf{c o}-(\mathbf{F}: \mathbf{I})_{0.52}$ copolymer (recorded in $\left.\mathrm{CDCl}_{3}\right)$.

Figure 7. Thermogravimetric analysis recorded under air of $(\mathbf{F}: \mathbf{C l})_{\mathbf{0 . 0 3}}-\mathbf{c o -}(\mathbf{F}: \mathbf{I})_{\mathbf{0 . 9 7}},(\mathbf{F}: \mathbf{C l})_{\mathbf{0 . 4 1}}$-co$(\mathrm{F}: \mathrm{I})_{0.59}$ and $(\mathrm{F}: \mathrm{Cl})_{0.05}-\mathrm{co}-(\mathrm{F}: \mathrm{E})_{0.64}-\mathrm{co}-(\mathrm{F}: \mathrm{I})_{0.31}$

Figure 8. $\mathrm{Tg}$ value $v s$ the iodine molar content for the poly(CTFE-co-VE) copolymers 


\begin{tabular}{|c|c|c|c|c|c|c|c|}
\hline \multirow[t]{2}{*}{ Copolymers } & \multicolumn{3}{|c|}{$\begin{array}{l}\text { Initial molar content } \\
\qquad(\text { mol \%) }\end{array}$} & \multicolumn{3}{|c|}{$\begin{array}{l}\text { Molar content in the copolymers } \\
\qquad(\mathrm{mol} \%)^{\mathrm{a}, \mathrm{b}}\end{array}$} & \multirow{2}{*}{$\begin{array}{c}\text { Massic } \\
\text { yield }(\%)^{\mathrm{c}}\end{array}$} \\
\hline & CTFE & CEVE & EVE & CTFE & CEVE & EVE & \\
\hline$(\mathrm{F}: \mathrm{Cl})$ & 50 & 50 & 0 & 50 & 50 & 0 & 75 \\
\hline$(\mathrm{F}: \mathrm{Cl})_{0.56}-\mathrm{co}-(\mathrm{F}: \mathrm{E})_{0.44}$ & 50 & 30 & 20 & 50 & $28^{\mathrm{b}}$ & 22 & 70 \\
\hline$(\mathrm{F}: \mathrm{Cl})_{0.36}-\mathrm{co}-(\mathrm{F}: \mathrm{E})_{0.64}$ & 50 & 20 & 30 & 50 & $18^{\mathrm{b}}$ & 32 & 70 \\
\hline
\end{tabular}

${ }^{a}$ Calculated from elemental analysis. ${ }^{b}$ Calculated from ${ }^{1} \mathrm{H}$ NMR. ${ }^{\mathrm{c}}$ Experimental mass of the purified copolymer divided by the sum of the monomer masses

Table 1. Experimental conditions and compositions of poly(CTFE-alt-CEVE) and poly[(CTFE-alt-CEVE)-co-(CTFE-alt-EVE)] copolymers where CTFE, CEVE and EVE stand for chlorotrifluoroethylene, 2-chloroethyl vinyl ether and ethyl vinyl ether, respectively. 


\begin{tabular}{ccc|cc|cc}
\hline & \multicolumn{2}{c|}{$(\mathbf{F}: \mathbf{C l})$} & \multicolumn{2}{c|}{$(\mathbf{F}: \mathbf{C l})_{\mathbf{0 . 5 6}}-\mathbf{c o -}(\mathbf{F}: \mathbf{E})_{\mathbf{0 . 4 4}}$} & \multicolumn{2}{c}{$(\mathbf{F}: \mathbf{C l})_{\mathbf{0 . 3 6}}-\mathbf{c o -}(\mathbf{F}: \mathbf{E})_{\mathbf{0 . 6 4}}$} \\
& cald & measd & cald & measd & cald & measd \\
\hline \% C & 32.31 & 32.16 & 34.41 & 34.46 & 35.59 & 35.70 \\
\hline \% H & 3.16 & 3.09 & 3.54 & 3.62 & 3.76 & 3.85 \\
\hline \% F & 25.55 & 26.12 & 27.24 & 27.27 & 28.17 & 28.44 \\
\hline \% Cl & 31.75 & 30.62 & 27.15 & 26.87 & 24.57 & 24.39 \\
\hline \% O & 7.23 & 8.01 & 7.65 & 7.78 & 7.91 & 7.62 \\
\hline
\end{tabular}

Table 2. Elemental analyses of poly(CTFE-alt-CEVE) and poly[(CTFE-alt-CEVE)-co-(CTFE-altEVE)] copolymers assuming alternating structures (where CTFE, CEVE and EVE stand for chlorotrifluoroethylene, 2-chloroethyl vinyl ether and ethyl vinyl ether, respectively) 


\begin{tabular}{|c|c|c|c|c|c|c|c|}
\hline & \multirow{2}{*}{$\mathrm{Mn}(\mathrm{g} / \mathrm{mol})$} & \multirow{2}{*}{ PDI } & \multicolumn{2}{|c|}{ TGA under nitrogen } & \multicolumn{2}{|c|}{ TGA under air } & \multirow{2}{*}{$\mathrm{T}_{\mathrm{g}, \exp }\left({ }^{\circ} \mathrm{C}\right)$} \\
\hline & & & $\mathrm{T}_{\mathrm{d}, 5 \%}\left({ }^{\circ} \mathrm{C}\right)$ & $\mathrm{T}_{\mathrm{d}, 10 \%}\left({ }^{\circ} \mathrm{C}\right)$ & $\mathrm{T}_{\mathrm{d}, 5 \%}\left({ }^{\circ} \mathrm{C}\right)$ & $\mathrm{T}_{\mathrm{d}, 10 \%\left({ }^{\circ} \mathrm{C}\right)}$ & \\
\hline$(\mathrm{F}: \mathrm{Cl})$ & 25000 & 2.8 & 300 & 320 & 250 & 265 & 27 \\
\hline$(\mathrm{F}: \mathrm{Cl})_{0.56}-\mathrm{co}-(\mathrm{F}: \mathrm{E})_{0.44}$ & 23000 & 3.0 & 315 & 335 & 260 & 277 & 25 \\
\hline$(\mathrm{F}: \mathrm{Cl})_{0.36}-\mathrm{co}-(\mathrm{F}: \mathrm{E})_{0.64}$ & 24000 & 3.1 & 325 & 340 & 270 & 285 & 26 \\
\hline
\end{tabular}

Table 3. Molecular weights, polydispersity indices and thermal properties of poly(CTFE-alt-CEVE) and poly[(CTFE-alt-CEVE)-co-(CTFE-alt-EVE)] copolymers. $\mathrm{T}_{\mathrm{d}, \mathrm{i} \%}$ stands for a thermal decomposition of $\mathrm{i} \%$ of the copolymer at the corresponding temperature (where CTFE, CEVE and EVE stand for chlorotrifluoroethylene, 2-chloroethyl vinyl ether and ethyl vinyl ether, respectively). 


\begin{tabular}{|c|c|c|c|c|c|c|c|c|c|}
\hline & \multicolumn{2}{|c|}{$\begin{array}{c}\text { Iodine substitution } \\
(\mathrm{mol} \%)\end{array}$} & \multirow[t]{2}{*}{$\operatorname{Mn}\left(\mathrm{g} \cdot \mathrm{mol}^{-1}\right)$} & \multirow[t]{2}{*}{ PDI } & \multicolumn{2}{|c|}{ TGA under nitrogen } & \multicolumn{2}{|c|}{ TGA under air } & \multirow[t]{2}{*}{$\mathrm{T}_{\mathrm{g}, \exp }\left({ }^{\circ} \mathrm{C}\right)$} \\
\hline & theo & $\exp$ & & & $\mathrm{T}_{\mathrm{d}, 5 \%}\left({ }^{\circ} \mathrm{C}\right)$ & $\mathrm{T}_{\mathrm{d}, 10 \%}\left({ }^{\circ} \mathrm{C}\right)$ & $\mathrm{T}_{\mathrm{d}, 5 \%}\left({ }^{\circ} \mathrm{C}\right)$ & $\mathrm{T}_{\mathrm{d}, 10 \%}\left({ }^{\circ} \mathrm{C}\right)$ & \\
\hline$(\mathrm{F}: \mathrm{Cl})_{0.03}-\mathrm{Co}-(\mathrm{F}: \mathrm{I})_{0.97}$ & 100 & 97 & 26000 & 2.7 & 282 & 297 & 285 & 298 & 41 \\
\hline$(\mathrm{F}: \mathrm{Cl})_{0.41}-\mathrm{co}-(\mathrm{F}: \mathrm{I})_{0.59}$ & 60 & 59 & 25500 & 2.6 & 299 & 311 & 298 & 312 & 37 \\
\hline$(\mathrm{F}: \mathrm{Cl})_{0.57}-\mathrm{Co}-(\mathrm{F}: \mathrm{I})_{0.43}$ & 40 & 43 & 25500 & 2.6 & 301 & 314 & 297 & 314 & 36 \\
\hline$(\mathrm{F}: \mathrm{Cl})_{0.04}-\mathrm{co}-(\mathrm{F}: \mathrm{E})_{0.44}-\mathrm{co}-(\mathrm{F}: \mathrm{I})_{0.52}$ & 56 & 52 & 23000 & 3.0 & 295 & 312 & 284 & 302 & 36 \\
\hline$(\mathrm{F}: \mathrm{Cl})_{0.05}-\mathrm{co}-(\mathrm{F}: \mathrm{E})_{0.64}-\mathrm{co}-(\mathrm{F}: \mathrm{I})_{0.31}$ & 36 & 31 & 20000 & 3.1 & 299 & 315 & 302 & 316 & 34 \\
\hline
\end{tabular}

Table 4. Iodine subsitution, molecular weights and thermal properties of poly(CTFE-alt-CEVE) and poly[(CTFE-alt-CEVE)-co-(CTFE-alt-EVE)] copolymers after nucleophilic subtitution with $\mathrm{NaI}$ (where CTFE, CEVE and EVE stand for chlorotrifluoroéthylène, 2-chloroethyl vinyl ether, and ethyl vinyl ether, respectively) 
Click here to download high resolution image
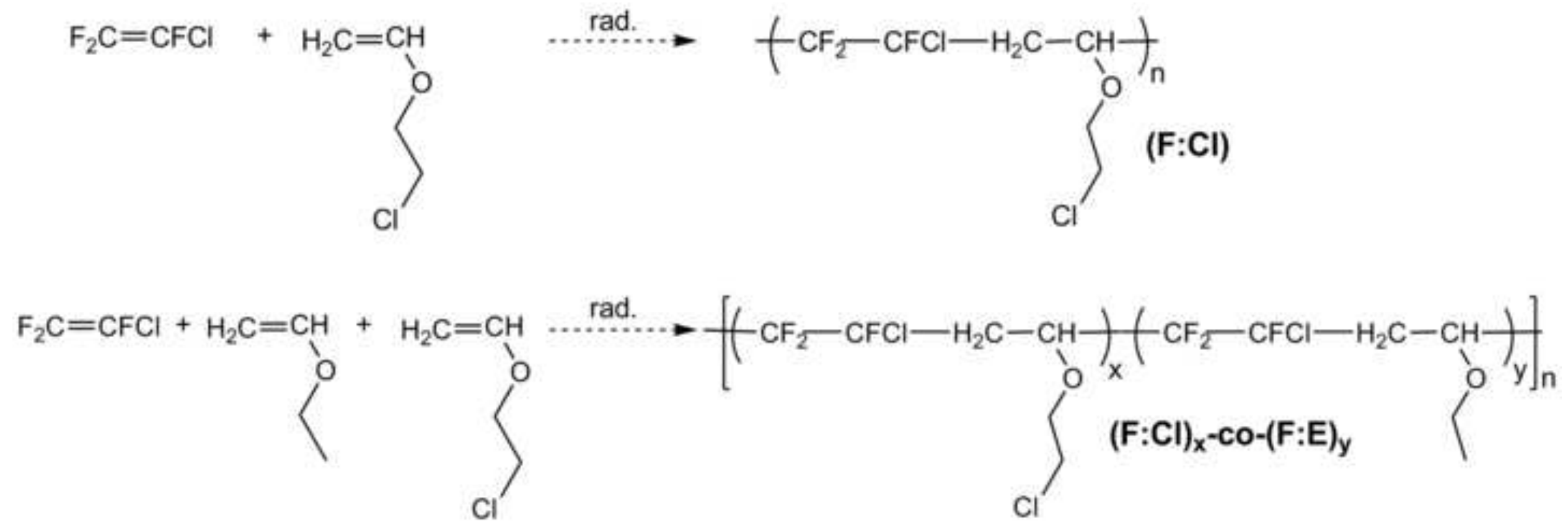

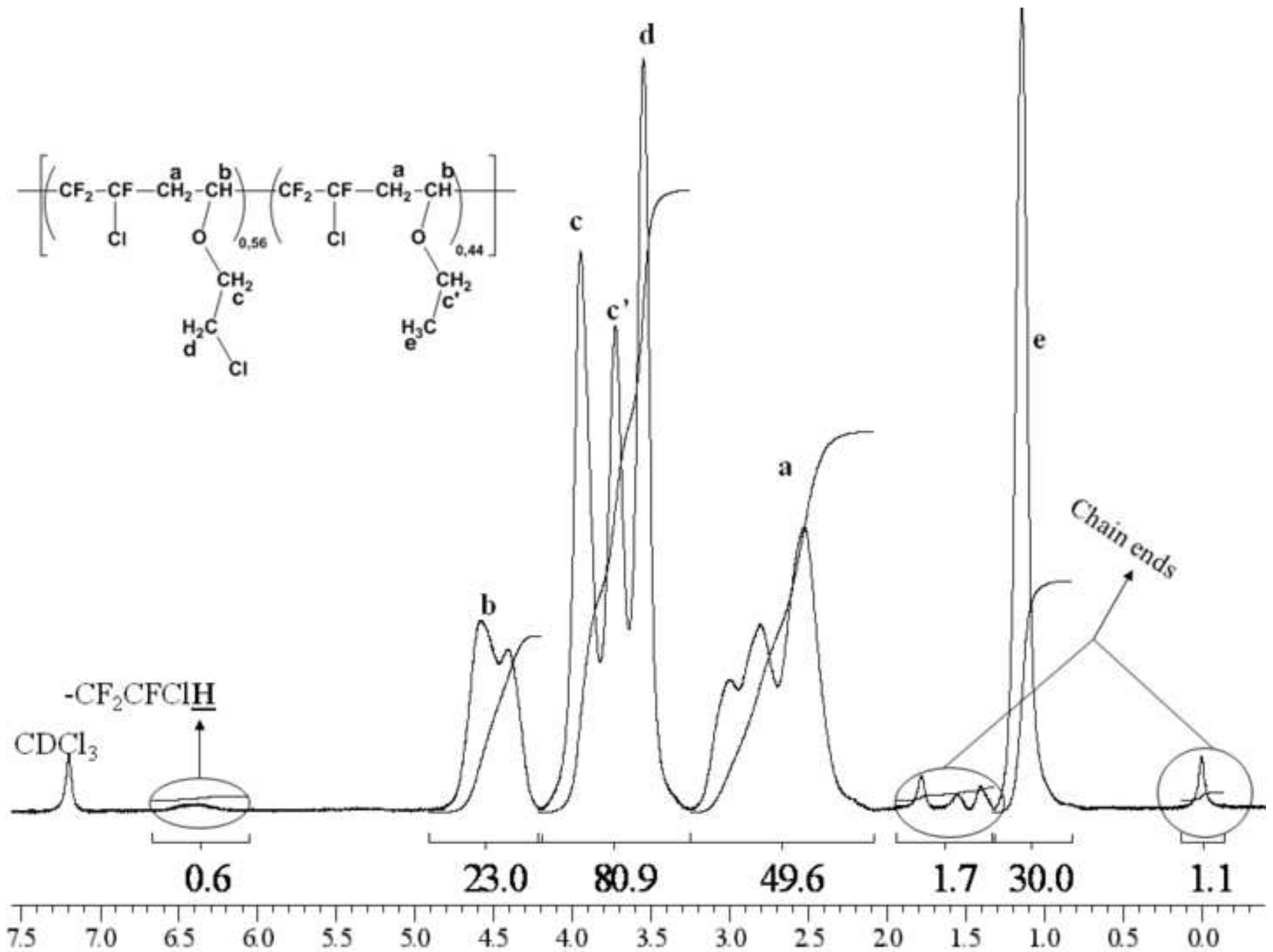


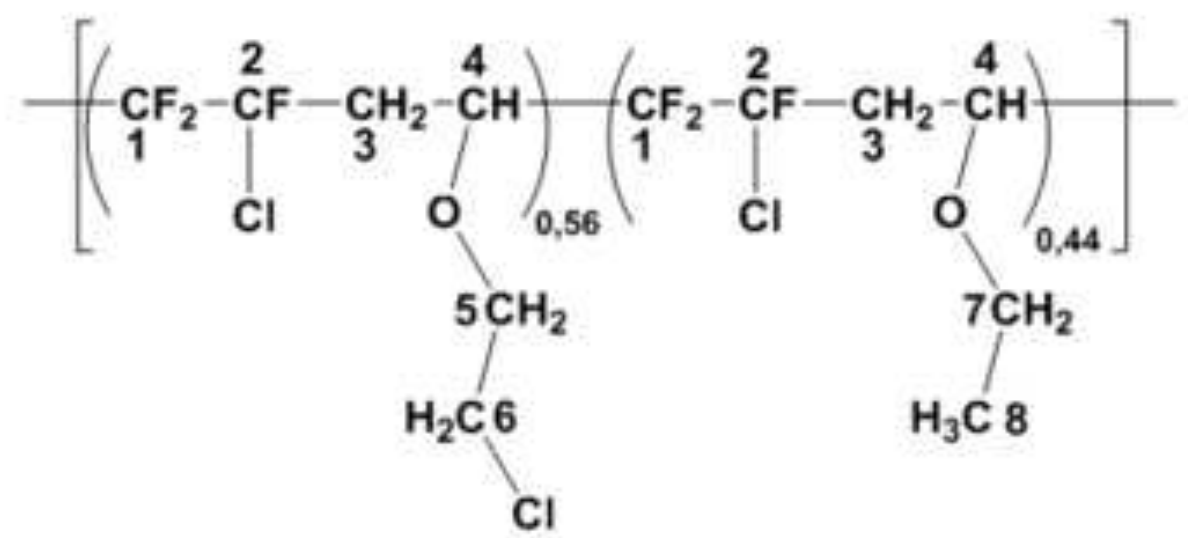

$\mathrm{CDCl}_{3}$
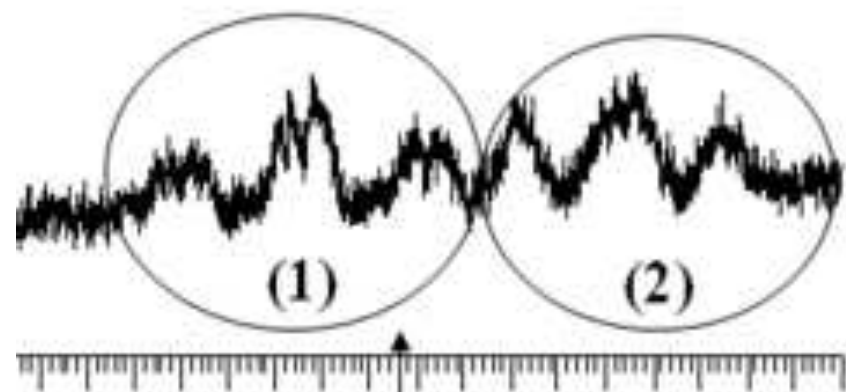
$12312121120119118117116 / 15114113112111110190108107106$
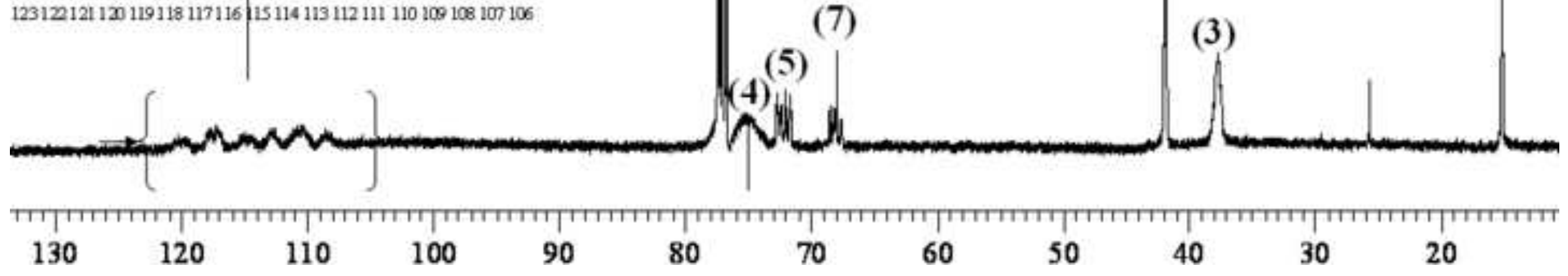


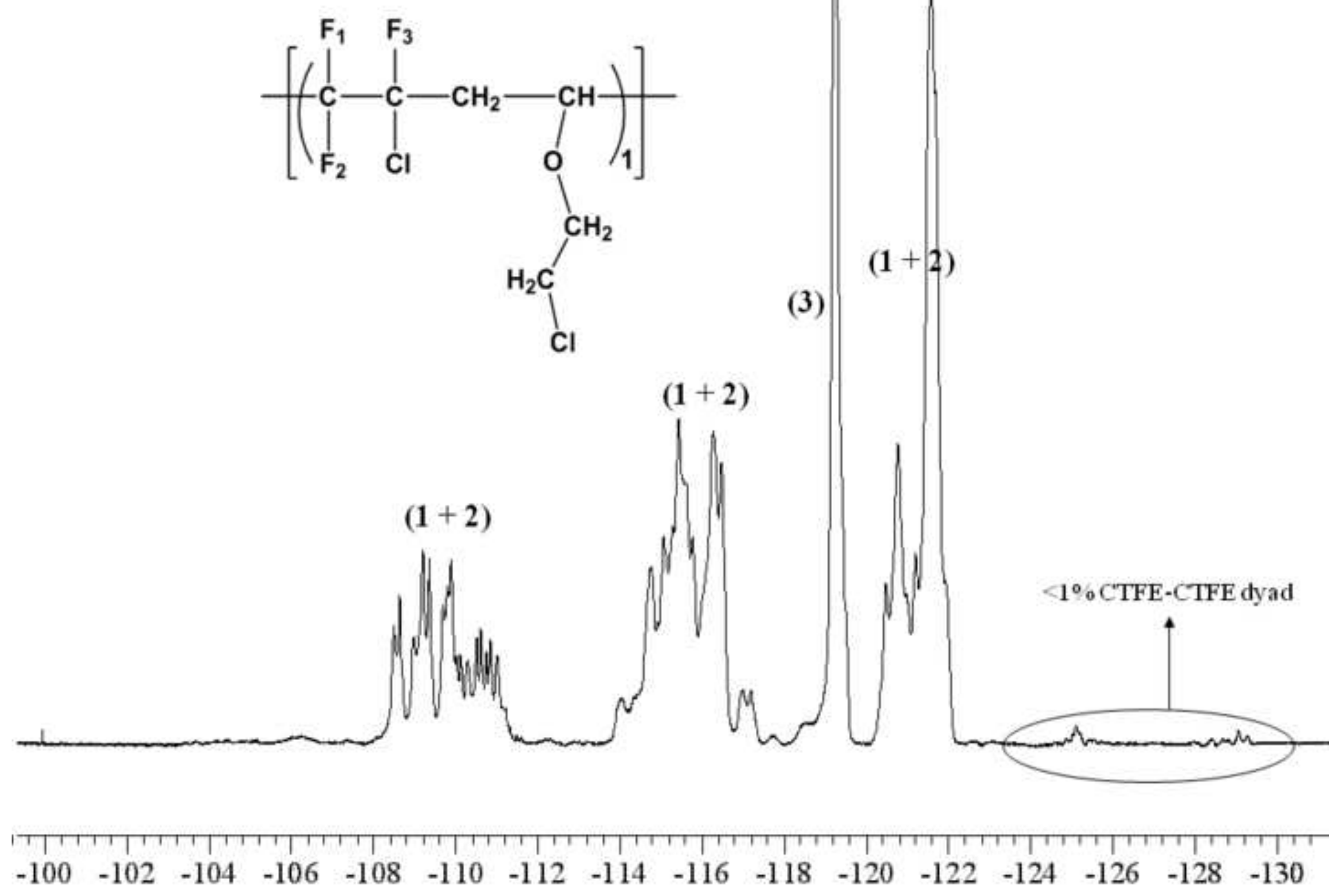



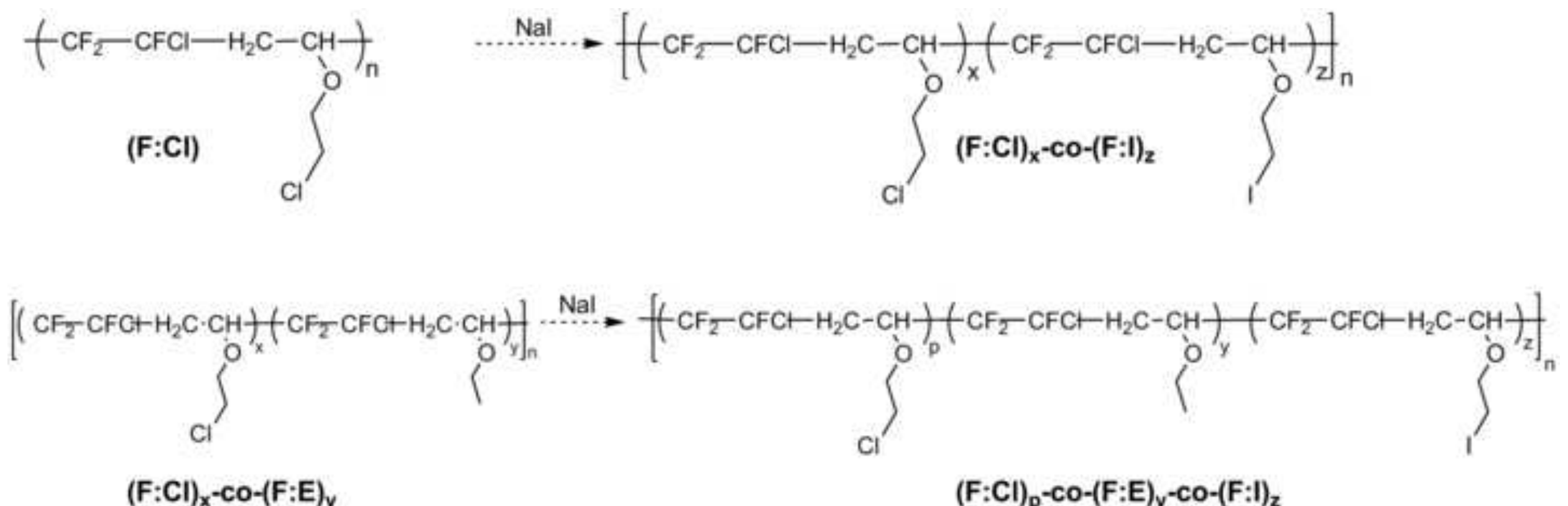

$(\mathrm{F}: \mathrm{Cl})_{\mathrm{x}}-\mathrm{co}-(\mathrm{F}: \mathrm{E})_{\mathrm{y}}$

$(\mathrm{F}: \mathrm{Cl})_{\mathrm{p}}-\mathrm{CO}-(\mathrm{F}: \mathrm{E})_{\mathrm{y}}-\mathrm{CO}-(\mathrm{F}: \mathrm{I})_{\mathrm{z}}$ 


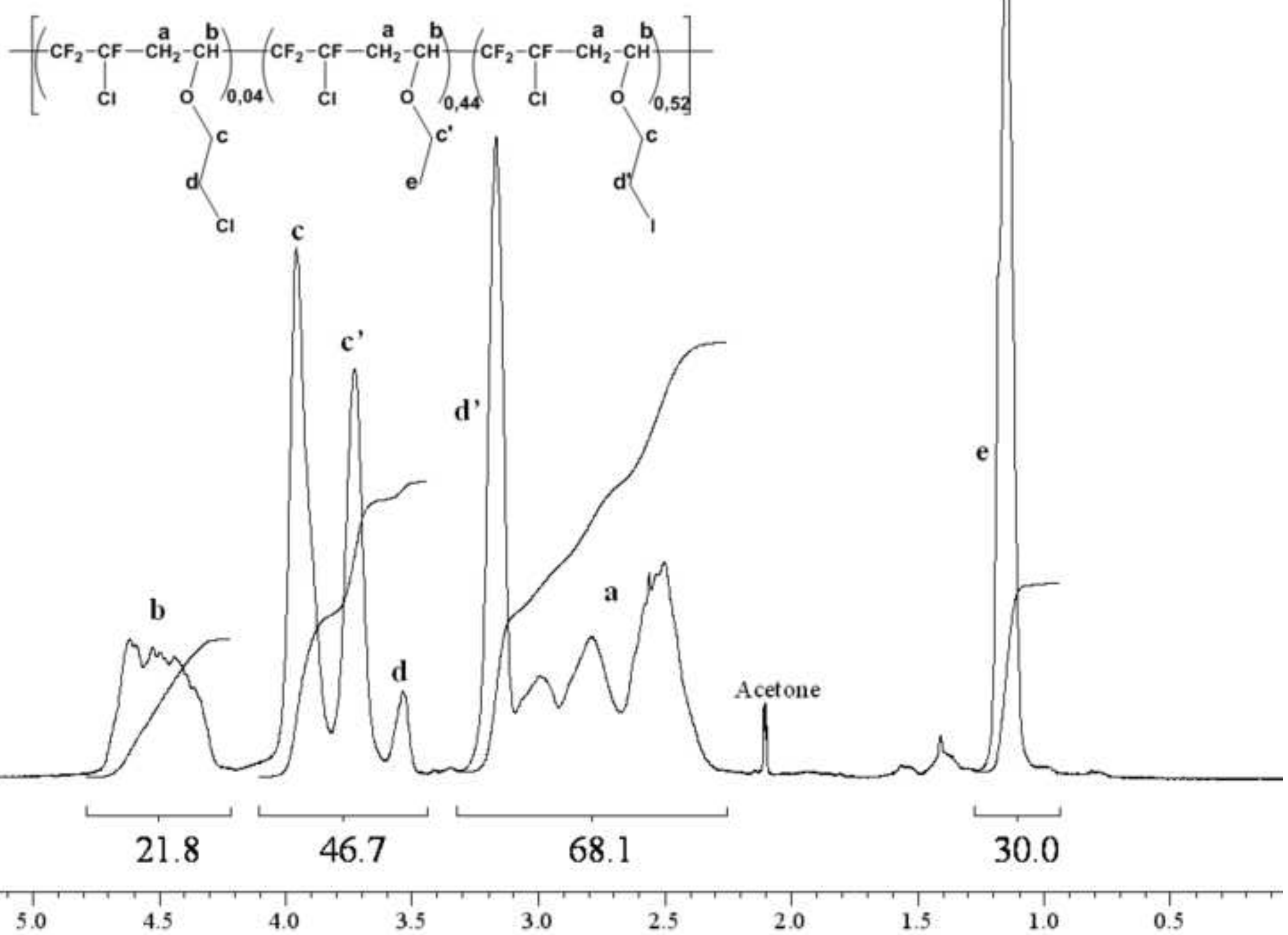


Click here to download high resolution image

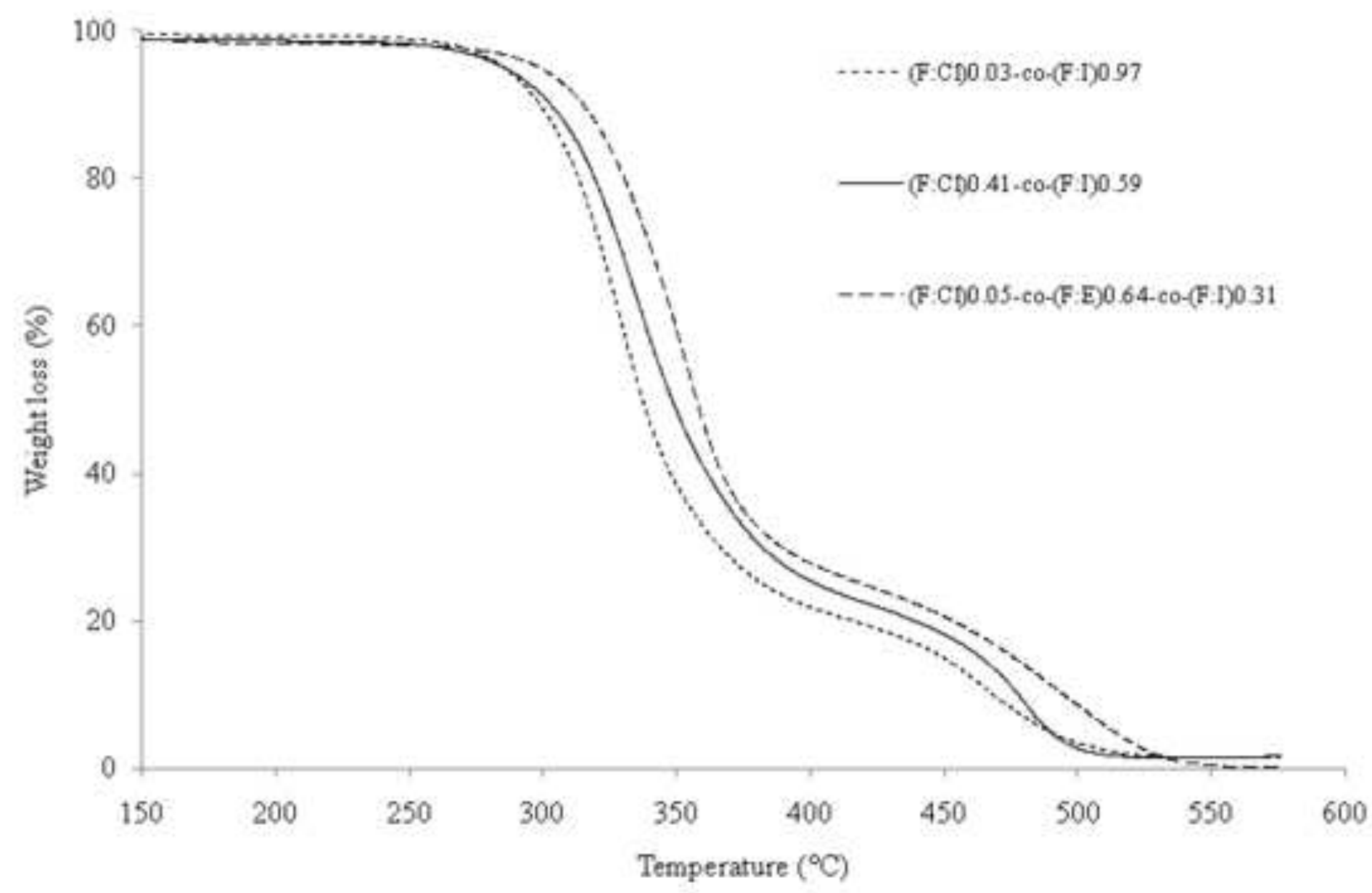


Figure(s)

Click here to download high resolution image

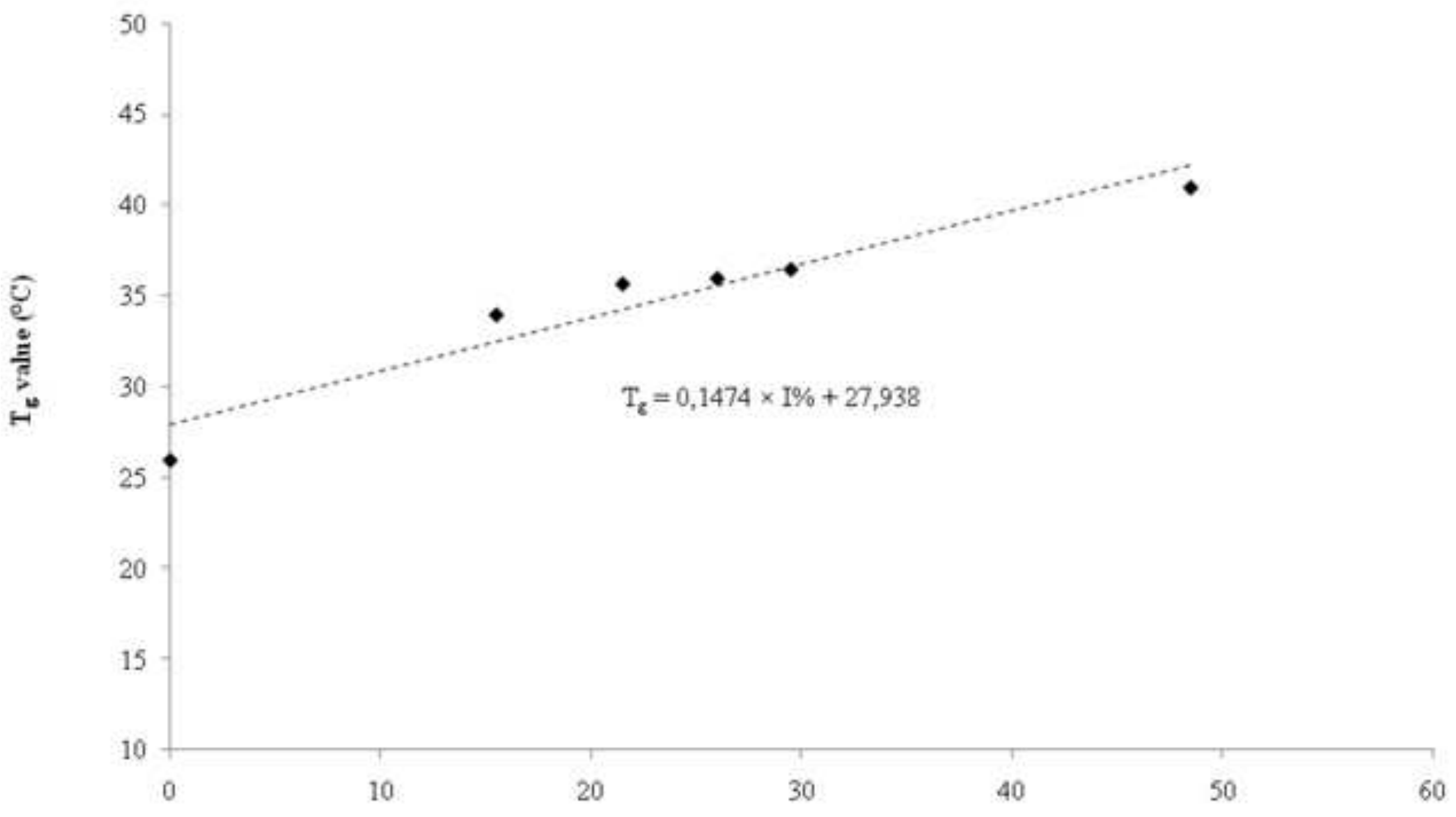

Iodine $(\% \mathrm{~mol})$ 